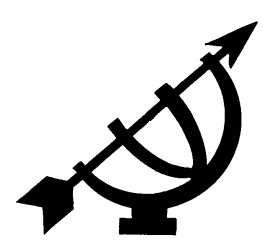

\title{
Kernaspekte van 'n model vir skoolsukses in arm gemeenskappe
}

\author{
G.D. Kamper \& M.E. Mampuru \\ Departement Opvoedkundestudies \\ Universiteit van Suid-Afrika \\ PRETORIA \\ E-pos: kampegd@unisa.ac.za
}

\begin{abstract}
Key aspects of a model for school success in poor communities

Some schools in impoverished communities are effective and successful in the face of the most difficult socio-economic circumstances and challenges. This phenomenon was investigated in a research project which had three phases. The first entailed a literature survey, culminating in a taxonomy of determinants of school success. The second phase consisted of the application of the taxonomy in field work in selected successful schools in impoverished communities. The third phase comprised interpretation of theoretical and empirical data, culminating in a model which depicts partnership as the central factor in all values and mechanisms pertaining to a successful school in an impoverished community. The model's potential value is indicated, inter alia in guiding schools in impoverished communities towards meaningful self-assessment and change.
\end{abstract}

\section{Opsomming}

Kernaspekte van 'n model vir skoolsukses in arm gemeenskappe

In arm gemeenskappe tref 'n mens soms skole aan wat effektief funksioneer ondanks haglike sosio-ekonomiese omstandighede. Hierdie verskynsel is ondersoek in 'n navorsingsprojek wat uit drie fases bestaan het. Die eerste fase het 'n literatuurstudie behels en dit het uitgeloop op 'n taksonomie van skoolsuksesdeterminante. Die tweede fase het bestaan uit die toepassing van die taksonomie in veldwerk wat uitgevoer is in vier geselekteerde suksesvolle skole in arm gemeenskappe. In 
die derde fase is die teoretiese en empiriese data geïnterpreteer met die oog op die ontwikkeling van 'n model wat die sleutelfaktore vir skoolsukses in arm gemeenskappe aandui. Die model toon vennootskap aan as die sentrale faktor in alle waardes en meganismes wat verband hou met 'n suksesvolle skool in 'n arm gemeenskap. Die model het verskeie aanwendingsmoontlikhede, onder andere om te dien as basis vir die ontwikkeling van 'n assesseringsinstrument waarmee skole in arm gemeenskappe self hulle sukseskoers kan bepaal.

\section{Inleiding}

Armoede is een van daardie verskynsels waarvan samevattend net gesê kan word: "Soveel hoofde, soveel sinne" - daar bestaan 'n groot aantal standpunte, teorieë en aannames oor die oorsake en meting daarvan. Oor die definisie van armoede bestaan daar wel ' $n$ groot mate van konsensus (Pieterse, 2001) en dit kom wesenlik neer op die onvermoë van individue, huishoudings of gemeenskappe om 'n sosiaal aanvaarbaarbare minimum lewenstandaard te verkry of te handhaaf vanweë 'n gebrek aan hulpbronne (cf. May \& Govender, 1998:9). Die term arm gemeenskap is vir die doeleindes van hierdie artikel van wesenlike belang. In aansluiting by die voorgaande definisie, gaan dit om 'n gemeenskap wat gekenmerk word deur hoë werkloosheid, honger en ondervoeding, die onvermoë om te betaal vir of toegang te kry tot basiese dienste en gesondheidsorg, disintegrasie van die familielewe, kwesbaarheid, dakloosheid en wanhoop (cf. RDP, 1995:3).

Inleidend word eers vier kernbegrippe in die verstaan en hantering van die armoedeproblematiek bespreek (met verwysing na armoede in Suid-Afrika), gevolg deur 'n kort teoretiese besinning oor die morele implikasies van die armoedeverskynsel. Daarna word 'n kort uiteensetting gegee van die impak van armoede op die skool, en die meegaande bestuurseise. Sodoende word die verwysingsraamwerk geskep vir die eintlike fokus van die artikel, naamlik 'n empiriese studie oor suksesvolle skole in arm gemeenskappe.

Die vier kernbegrippe in die armoedeproblematiek is absolute armoede, relatiewe armoede, armoedespiraal en armoedegaping.

Die term absolute armoede is eintlik selfverklarend. Dit gaan oor armoede as 'n oorlewingstryd, en die norm vir die bepaling daarvan is gewoonlik die sogenaamde armoedelyn, of broodlyn, wat neerkom op 'n minimum daaglikse kalorie-inname (2 000 kalorieë) wat nodig is vir oorlewing (Kamper, 2001:110). Die Wêreldbank heg 
'n monetêre waarde aan die armoedelyn, waarvolgens mense wat oor minder as een dollar per dag beskik (omgereken ongeveer R300 per maand), as sorgwekkend baie arm geklassifiseer word (cf. Terreblance, 2004:213). Die vlak van absolute armoede (dit wil sê die persentasie van die bevolking wat onder die sogenaamde broodlyn leef) in Suid-Afrika is ontstellend. Indien 'n mens die broodlyn op 'n daaglikse inname van 2000 kalorieë vasstel, bevind $40 \%$ van die Suid-Afrikaanse bevolking hulself in absolute armoede (Kamper, 2001:110). Werkloosheid is algemeen - van die armes wat geskik is vir werk het minder as $30 \%$ daadwerklik werk - 'n situasie wat vererger word deur die feit dat $72 \%$ van die land se armes in landelike gebiede woon (Kamper, 2001:110.). Die betreurenswaardigste aspek van Suid-Afrika se armoedeprobleem (in absolute $\sin$ ) is dat dit steeds groeiend is, nieteenstaande die politieke verandering van 1994 (Terreblanche, 2004:213-214).

Vir die bepaling van relatiewe armoede geld norme soos die gemiddelde per capita inkomste in 'n bepaalde provinsie, streek of woonbuurt, relatief tot die gemiddelde in die land. Baie ander norme, soos die mate van toegang tot onderwys en basiese gesondheidsorg, of die stand van elektrisiteits- en watervoorsiening in 'n bepaalde streek, relatief tot die gemiddelde stand daarvan in die land, kan geld. Die navorsinginstansie Research Surveys het 'n armoede-indeks ontwerp wat gebaseer is op die toegang tot basiese en telekommunikasiedienste, en volgens die jongste jaarlikse lewenskwaliteitopname volgens hierdie indeks (waar 'n telling van 50 of hoër op armoedige omstandighede dui) ly gemiddeld $39 \%$ van die Suid-Afrikaanse bevolking onder armoede, met verhoudingsgewys die hoogste intensiteit in plattelandse gebiede (gemiddelde telling 63) en in stedelike informele nedersettings (gemiddelde telling 60) (Research Surveys, 2005:1).

Die term armoedespiraal, en verbandhoudende terme soos armoedestrik (poverty trap) en armoedevangrat (poverty ratchet) is inherent aan teorievorming oor die armoedeverskynsel sowel as aan armoedebekampingsmaatreëls. Dit kom daarop neer dat die oorsake en uitwerking van armoede 'n bose kringloop en netwerk vorm met pole van isolasie, magteloosheid, kwesbaarheid en fisiese swakheid (Chambers, 1994:111-114) waaraan slagoffers van armoede asook hulle nakomelinge baie moeilik kan ontkom. Materieel beteken dit dat arm gebiede, ondanks ontwikkelingsprojekte van allerlei aard, geneig is om arm te bly. Psigologies en sosiologies beteken dit dat arm mense vasgevang raak in 'n spiraal van negatiwiteit. Volgens Clinard (1970:329) se treffende 
beskrywing van die sosiologiese en psigologiese konsekwensies van armoede, toon arm gemeenskappe gewoonlik min belangstelling in persoonlike en gemeenskapsontwikkeling. Kenmerkend is die apatie jeens (voorgestelde) selfhulpinisiatiewe vanweë 'n selfpersepsie van magteloosheid en uitgeworpenheid. Hierdie lewensinstelling loop gewoonlik uit op selfgelding in die vorm van maatskaplike probleme soos verslawing, geweld en misdaad.

Die term armoedegaping dui op die bedrag wat jaarliks nodig is om armoede uit te wis deur 'n geteikende oordrag aan die armes. Daar word geraam dat dit in Suid-Afrika jaarliks tussen R20 en R30 miljard sal kos (Terreblance, 2004:233), addisioneel tot die bestaande begroting, vir armoedehulp.

Die armoedegaping hou ook verband met die ryk-arm-digotomie, wat in Suid-Afrika en Brasilië die hoogste ter wêreld is en steeds vergroot (Kamper, 2001:110). Volgens die Sentrale Statistiekdiens verdien die rykste $10 \%$ van die bevolking $48 \%$ van die totale inkomste van die land; die armste $10 \%$ ontvang net $1 \%$ van die inkomste (Pieterse, 2001:56).

Uit hierdie kort uiteensetting blyk die kompleksiteit en impak van die armoedeverskynsel alreeds duidelik. Pieterse (2001:34) konstateer treffend na aanleiding van die armoedestatistiek in Suid-Afrika:

Hierdie syfers moet enige regdenkende mens met iets van 'n sosiale gewete tot in die diepste van sy wese skud ... Soos die aaklige prentjie voor ons ontvou, naamlik 'n prentjie van die ellende wat in ons land deur arm mense ervaar word, sal die besef oor wat om ons aangaan hopelik al dieper in ons gemoedere indring.

\section{Morele implikasies van die armoedeprobleem}

Kamper (2001) toon aan hoe die oorsake en voortsetting van die armoedeverskynsel vanuit demografiese, ekonomiese, ekologiese, psigologiese, sosiologiese en morele perspektiewe verstaan en omskryf kan word, veral met die oog op onderwysvoorsiening. Hierdie breë verwysingsraamwerk is belangrik, maar kan weens beperkte ruimte nie volledig hier bespreek word nie.

Vir die doeleindes van hierdie artikel val die klem op enkele morele implikasies van die armoedeverskynsel.

Die morele imperatief betreffende hulp aan armes word in die Bybel onder andere in Deuteronomium 15:11 verwoord: "Want die arme 
sal in die land nie ontbreek nie, daarom gee ek jou bevel en sê: Jy moet jou hand wyd oopmaak vir jou broer, vir die ellendige en arme in jou land."; Matteus 6:3-4: "Nee, as jy iets vir die armes gee, moet jou linkerhand nie weet wat jou regterhand doen nie, sodat jou goeie daad verborge kan bly. Jou Vader wat sien wat verborge is, sal jou beloon."; Handelinge 20:34-35: 'n mens moet hard werk sodat jy die armes kan help, en: "Dit is saliger om te gee as om te ontvang"; Matteus 25:36: praktykmaking van godsdiens behels hulp aan minderbevoorregtes: "Ek was naak, en julle het my geklee; Ek was siek, en julle het my besoek, ...". Hierdie imperatiewe kulmineer in die liefdesgebod: "Jy moet jou naaste liefhê soos jouself" (Mark. 12:29-31). Vanuit Bybelse perspektief mag daar dus nooit sprake wees van onbetrokkenheid en onbehulpsaamheid jeens armes nie, veral omdat alle besittings gawes van die Here is en as sodanig ook gedeel moet word met noodlydendes. "Wie maak jou so belangrik? En wat besit jy wat jy nie ontvang het nie?" (1 Kor. 4:7).

In 'n weldeurdagte en toepaslike beredenering gee Kritzinger (1996:12-19) vanuit Christelike perspektief die "kontoere van 'n nuwe benadering" tot die armoedevraagstuk. Hy beklemtoon daarin die volgende:

- 'n Nuwe ingesteldheid by die bevoorregtes: soberheid. Bevoorregtes kan nie aanhou lewe asof daar geen armoede is nie, maar sal daadwerklik deur ' $n$ eenvoudiger lewenstyl moet begin werk aan die gaping tussen ryk en arm.

- 'n Nuwe verstaan van die arme: respek. Armes se waardigheid as mense moet erken word en hulle moet regmatig betrek word by besluitneming oor hulle toekoms.

- 'n Nuwe radikale ideaal: transformasie. Dit gaan om veel meer as "ontwikkeling" (in ekonomiese sin) en "bevryding" (in politieke sin) - dit gaan om transformasie van die totaliteit van die persoon ook die lewens- en wêreldbeskouing word geraak. (Kritzinger het hier ' $n$ transformasie in Christelike sin, naamlik van die oue na die nuwe mens in die oog. Die nuwe mens, arm of ryk, beskou die eie en ander se situasie in terme van dankbaarheid en diens.)

- 'n Nuwe strategie: saam. Praktykervaring wys duidelik dat 'n benadering "van bo" (neerbuigend, beterweterig) en die korrektief daarop, naamlik "van onder" (uitsluitlik plaaslike inisiatiefname) nie die gewenste resultate oplewer nie. Samewerking van mense binne en buite die betrokke gemeenskap hou die sterkste 
moontlikhede in, maar met 'n instelling van ware wedersydse openheid en afhanklikheid.

- 'n Nuwe metode: verhoudings. Persoonlike verhoudings en wedersydse vertroue moet gebou word deur op grondvlak met die nood en situasie van armes te identifiseer.

Hierdie "kontoere" dien prinsipieel as die teoretiese vertrekpunte vir, en die besinningsraamwerk waarbinne die aanpak van die armoedeproblematiek (ook by wyse van onderwysvoorsiening) verstaan en onderneem behoort te word. Toegepas op die onderwysvoorsiening hou hierdie "kontoere" in dat ouers en leerders in arm gemeenskappe gerespekteer word met 'n onbevange erkenning van hulle aanspraak op kwaliteitonderwys, en 'n geloof in hulle vermoëns om 'n konstruktiewe onderwysomgewing te skep en te handhaaf.

\section{Impak van armoede op onderwysvoorsiening}

Dit spreek vanself dat onderwysvoorsiening aan armes wesenlik te make het met 'n bevryding uit die greep en suigkrag van armoede, soos dit treffend deur die metafore spiraal, strik en vangrat verbeeld word. Talle ondersoeke het in die verlede al getoon dat die één enkele faktor wat armoede kan ophef, 'n verhoogde onderwyspeil is (Pieterse, 2001:40)

Die sosio-ekonomiese en sosiologiese probleme verbonde aan armoede hou vir ordelike, effektiewe en gelyke onderwysvoorsiening spesifieke uitdagings in, omdat arm leerders en arm skole prinsipieel-opvoedkundig op dieselfde kwaliteit van onderwysvoorsiening geregtig is as hulle welgestelde eweknieë. Gevolglik word skole landswyd in vyf kategorieë (quintiles) verdeel van arm tot welgesteld en hulle word ook sodanig befonds. Vir die identifisering van arm skole word die relatiewe armoede van die gemeenskap in ag geneem, gebaseer op die gemiddelde inkomste in die gemeenskap. Dergelike kriteria word ook gebruik om vrystelling van skoolfooie te bepaal, en te verseker dat arm leerders wel welgestelde skole kan bywoon. Die omvang van armoedegebaseerde skolebefondsing word duidelik uit statistiek betreffende die persentasie skole per provinsie in die eerste twee armoedekategorieë: Oos-Kaap (60\%); Vrystaat (53\%); Gauteng (18\%); KwaZulu-Natal (41\%); Limpopo (52\%); Mpumalanga (37\%); NoordKaap (35\%); Noord-Wes (39\%) en Wes-Kaap (14\%) (NAPTOSA, 2003:2). 
Die werklike impak van armoede op onderwysvoorsiening blyk die beste uit die meegaande opsomming van leerder-, onderwyser- en omgewingsgesteldheid waarmee die hoof van 'n skool in 'n arm gemeenskap tipies gekonfronteer kan word.

- Leerders (Cole-Henderson, 2000:84; Acker-Hocevar \& Touchton, 2000a): honger; siek; min klere; fisiese gevaar (bv. deur bendebedrywighede); oorlewingsaksies (soos prostitusie, misdaad); geen studiegeriewe; geen ouersteun; geen rolmodelle; geen informele onderwys uit boeke, koerant, internet; lae selfbeeld; geen leermotivering; gebrekkige taalvermoë; tart enige gesag; verwissel dikwels van skool.

- Onderwysers (Cole-Henderson, 2000:86; Haberman, 1999: 3, 4, 5, 11; Acker-Hocevar \& Touchton, 2000b): dikwels beginneronderwysers; dikwels ondergekwalifiseerd; mobiliteit - goeie onderwysers soek beter werkomgewings; ongemotiveerd; dikwels afwesig (gewoonlik stresverwant); min inisiatief; "uitbrand"; lae leerderverwagtings; lae skoollojaliteit; geen leerderrespek; geen oueragting; minderwaardigheidsgevoel; onkreatiewe drilonderwys ("armoede-pedagogiek"); vervalle klaskamers; geen hulpbronne; fisiese gevaar (vanweë leerderaggressie en buurtmisdaad).

- Skoolomgewing (Shanklin et al., 2003:357; Acker-Hocevar \& Touchton, 2000b): onversorgde skoolterrein; vervalle, onversorgde geboue; vernielde en ontoereikende meubels; geen vullisgeriewe; swak toiletgeriewe; gevaarlik (bv. deur swak elektriese bedrading); swak basiese onderhoud; deel van afgetakelde gemeenskapsmilieu.

Die skoolbestuurseise wat deur die voorgaande opsommings geïmpliseer word, is gedug. Dit verbaas dus geensins nie dat onsuksesvolle, "sinkende" skole (Stoll \& Fink, 1996: 86) meestal in arm gebiede voorkom (Glidden, 1999:21-22). Wesenlik impliseer die bestuurseise 'n radikale ommekeer, as't ware 'n skoolreformasie en standhoudende opbou betreffende toekomsvisie, standaarde, verwagtings, kultuur, dienslewering, hulpbronne en kommunikasie, met gehalte-onderwys as mikpunt en kriterium. In praktiese terme kan die bestuursuitdaging die beste as 'n vraag verwoord word: Hoe kan al die armoede-verwante agterstande betreffende leerders, ouers, onderwysers, hulpbronne en infrastruktuur oorkom word, en 'n effektiewe en gelukkige leeromgewing geskep word?

In die lig van die armoede- en verbandhoudende onderwysvoorsieningsproblematiek is dit baie opvallend dat sommige skole in 
arm gemeenskappe wel die antwoord op die voorgaande vrae gevind het, dit wil sê skole wat effektief funksioneer en uitnemend presteer in terme van sigbare en bepaalbare prestasie soos byvoorbeeld in openbare eksamens (Day, 2005; Harris, 2002; Revilla \& De La Garza Sweeney, 1997; Jacobson et al., 2005; Jesse, Davis \& Pokorny, 2004; National Commision on Education, 1996). Hierdie verskynsel was die fokus van die ondersoek. Daar is aangeneem dat gevallestudies waarin die eienskappe van suksesvolle skole in arm gemeenskappe empiries bepaal en geïnterpreteer word ' $n$ hulpmiddel kan wees om die peil van onderwysvoorsiening in arm gemeenskappe te verhoog. Die uiteindelike oogmerk met die navorsing was om die determinante van skoolsukses in ' $n$ arm gemeenskap in ' $n$ model te integreer, in die veronderstelling dat so 'n model waardevol kan wees in strategieë en maatreëls om die gehalte van skoolbestuur in arm gemeenskappe te verbeter.

Die navorsingsprojek het uit drie fases bestaan. Die eerste fase het 'n literatuurstudie behels wat uitgeloop het op 'n taksonomie van generiese skoolsuksesdeterminante. Die tweede fase het bestaan uit die toepassing van die taksonomie in veldwerk wat uitgevoer is in geselekteerde suksesvolle skole in arm gemeenskappe, ten einde vas te stel watter suksesdeterminante moontlik in die besonder in arm skole geld. In die derde fase is die teoretiese en empiriese data geïnterpreteer, met die oog op die ontwikkeling van 'n model van sleutelfaktore in die verwesenliking van skoolsukses in arm gemeenskappe.

\section{Raamwerk vir data-analise}

In die literatuurstudie is onder andere afgekom op 'n verslag van die (Britse) National Commission on Education (NCE), getiteld Success against the odds: effective schools in disadvantaged areas (NCE, 1996). Die fokus en bevindings van hierdie verslag was spesifiek ter sake vir die onderhawige navorsing, en het waardevolle riglyne voorsien. Die NCE-projek het elf skole (wat gewissel het van primêre skole tot komprehensiewe skole) betrek wat volgens amptelike inspeksiekriteria as suksesvol geïdentifiseer is ten spyte van die moeilike omstandighede waarin die skole moes funksioneer. Elke skool is deur 'n paneel besoek wat bestaan het uit 'n onderwys-, 'n sake- en 'n gemeenskapsontwikkelingskundige. Die metodologie het voorsiening gemaak vir verskeie besoeke, waartydens onderhoude met belanghebbendes, observasies van skoolpraktyk en analises van skooldokumente kon plaasvind (NCE, 1996:8-10). Die funksionaliteit van die assesseringsraamwerk wat deur een van 
hierdie panele gebruik is, het veral die oog gevang. Dit onderskei bloot tussen waardes en meganismes ten einde skoolsukses te verseker, en lys daarvolgens die volgende sleutelsuksesfaktore (NCE, 1996:159-167):

- Waardes: duidelike doelstellings en etos; fokus op leer en prestasie; hoë verwagtings; fokus op kwaliteit; kollegialiteit.

- Meganismes: leierskap; bestuur; kommunikasie; monitering; deelnemende besluitneming; ouer- en gemeenskapsbetrokkenheid.

Die opsommende bevinding was dat die NCE-verslag (NCE, 1996) die rol van visionêre, deelnemende leierskap beklemtoon in die vestiging en voortdurende verbetering van suksesvolle skole in arm gemeenskappe. Sonder om dit spesifiek te beklemtoon, het een tema soos die spreekwoordelike goue draad deur die verslag gevleg, naamlik die tema verwagtinge. Hieruit kon die aanname gemaak word dat die sukses van skole in arm gemeenskappe in 'n groot mate 'n funksie is van die verwagtings van al die belanghebbendes in die skool.

Vanuit hierdie verwysingsraamwerk het Mampuru (2003) eers 'n uitgebreide literatuurstudie gedoen oor generiese aspekte van skoolsukses, as basis vir die latere identifisering van skoolsuksesaspekte wat spesifiek in arm skole mag geld. Die literatuurstudie het die volgende temas gedek: opvoedkundige leierskap, veranderingsbestuur, totale kwaliteitsbestuur, totale kwaliteitsonderwys, verbetering van skole, effektiwiteit van skole en die skool as leerorganisasie (Bowring-Carr, 1997; Davies, 1997; English \& Hill, 1994; Farrell, 1994; Gewirtz, 1998; Gonder, 1983; Horne \& Brown, 1997; Lewis, 1993; Marishane, 1999; Moloi, 2002; Parsons, 1994; Purkey, 2000; Reid, Hopkins \& Holly, 1987; Sallis, 1992; Scheets \& Benson, 1994; Townsend, 1997; Visscher, 1999; WestBurnham, 1992). Uiteindelik is die volgende 34 determinante van skoolsukses geïdentifiseer (Mampuru, 2003:9-10): 
- Beleid oor leerdergedrag - Gebruik ouers en

- Belonings en dryfvere wat leerders aanmoedig om te slaag

- Bestuur deur rondstap

- Bestuursparadigma: beplanning, organisering, leiding en kontrolering

- Betrokkenheid van personeel en leerders

- Betrokkenheid van ouers en gemeenskap

- Buitemuurse aktiwiteite

- Deelnemende leierskapstyl

- Deelnemende besluitneming

- Delegering

- Deurlopende terugvoer

- Fokus op totale kwaliteitsbestuur gemeenskap om onderrig te ondersteun

- Gereelde dinkskrums

- Goeie kommunikasievaardighede

- Hoë en konsekwente verwagtings

- Koppel skoolbeleid en personeelontwikkelingsbeleid

- Mentorskap en toepaslike opleidingsdoelwitte

- Mikpunte vir leerders en opvoeders

- Monitering

- Motivering van en deur leerders en opvoeders

- Onderhandelings- en luistervaardighede

- Oopdeurbeleid (leerders, personeel, ouers en gemeenskap)

- Opbou van goeie verhoudings met alle belanghebbers
- Optimale gebruik van eksterne "kritiese vriende"

- Selfassessering deur leerders, opvoeders en skoolbestuur

- Spanwerk

- Terugvoering aan leerders en belanghebbers ten einde leer en onderrig te verbeter

- Toerekenbaarheid

- Toewyding aan die visieen missiestelling

- Tydsbestuur

- Veiligheid en sekuriteit

- Vennootskap vir verandering

- Verbintenis tot voortreflikheid

Hierdie determinante is in vier temas gekategoriseer, naamlik Bestuur, Motivering, Deelname en Evaluering en in 'n taksonomie vervat (Mampuru, 2003:10-11) soos hierna aangetoon.

Die determinante in Mampuru se taksonomie (Mampuru, 2003:1011) het alreeds beduidende ooreenkoms vertoon met die faktore wat in die NCE-verslag geïdentifiseer is (NCE, 1996). Daar is gevolglik besluit om die taksonomie as ' $n$ verwysingsraamwerk vir die tweede fase (die veldwerk) van die navorsing te gebruik. Die veldwerk was daarop gemik om die items in die taksonomie empiries te verifieer, 
met moontlike beklemtonings soos wat dit vir suksesvolle arm skole sou geld. Die uiteindelike verwagting was dat die data sou kon dien as basis vir 'n model van skoolsuksesfaktore in arm gemeenskappe.

\begin{tabular}{|c|c|}
\hline \multicolumn{2}{|c|}{ Taksonomie van skoolsuksesdeterminante } \\
\hline Bestuur & Deelname \\
\hline Beginsels: & Beginsels: \\
\hline $\begin{array}{l}\text { Totale kwaliteitsbestuur } \\
\text { Leierskanstvl }\end{array}$ & Visie- en missiestelling \\
\hline Beleid: & Praktyk: \\
\hline $\begin{array}{l}\text { Skool- en personeelontwikkeling } \\
\text { Oopdeur } \\
\text { Leerdergedrag }\end{array}$ & $\begin{array}{l}\text { Betrokkenheid van personeel en } \\
\text { leerders } \\
\text { Spanwerk } \\
\text { Kommunikasie en onderhandeling } \\
\text { Betrokkenheid van ouers en die } \\
\text { gemeenskap }\end{array}$ \\
\hline Praktyk: & \\
\hline $\begin{array}{l}\text { Beplanning } \\
\text { Organisering } \\
\text { Leiding } \\
\text { Kontrolering }\end{array}$ & \\
\hline Motivering & Evaluering \\
\hline Beginsels: & Beginsels: \\
\hline $\begin{array}{l}\text { Hoë verwagtings } \\
\text { Verbintenis tot voortreflikheid }\end{array}$ & Toerekenbaarheid \\
\hline Praktyk: & Praktyk: \\
\hline $\begin{array}{l}\text { Motivering van leerder en opvoeder } \\
\text { Opleiding en mentorskap } \\
\text { Veiligheid en sekuriteit } \\
\text { Belonings en dissiplinêre aksie }\end{array}$ & $\begin{array}{l}\text { Evaluering van opvoeder } \\
\text { Evaluering van leerder } \\
\text { Evaluering van hele skool }\end{array}$ \\
\hline
\end{tabular}

\section{Navorsingsontwerp}

Gevallestudies is beskou as die beste wyse van veldwerk om die etos, atmosfeer en funksionering van suksesvolle skole in arm gemeenskappe te bepaal. 'n Gevallestudie bied die geleentheid om 'n diepgaande ideografiese ondersoek van doelmatig geselekteerde 
individue, organisasies of gemeenskappe uit te voer, en verskaf gewoonlik ryk beskrywende data (Terre Blanche, Durrheim \& Painter, 2006:460-461). Die metodologie het voorsiening gemaak vir onderhoude met individue en fokusgroepe, observasie deur rond te stap, en die ontleding van beleidsdokumente.

Om die veldwerk hanteerbaar en uitvoerbaar te hou, is besluit om dit te beperk tot vier sekondêre skole in die Gautengprovinsie. Twee skole was geleë in 'n stedelike omgewing en die ander twee in landelike gebiede. Die skole is geïdentifiseer met behulp van 'n lys van die matrikulasieslaagsyfers van sekondêre skole in Suid-Afrika (soos gepubliseer in die Sunday Times van 2002-02-24; vgl. Anon., 2002). Die fokus op sekondêre skole is op twee oorwegings gegrond. Eerstens op matrikulasie-eksamenuitslae wat in die openbare domein die sigbaarste en mees praktiese maatstaf vir die effektiwiteit van skole is. Tweedens is aangeneem dat die bevindings betreffende die sukses van sekondêre skole in 'n groot mate toepaslik sou wees op die bestuur van primêre skole. Die selektering van skole uit sowel stedelike as landelike omgewings is gebaseer op die feit dat hierdie omgewings verskillende kontekste van armoede verteenwoordig (byvoorbeeld dat werkloosheid gewoonlik erger is in landelike gebiede; Kamper, 2001), en skole dus op verskillende wyses kan beïnvloed.

Individuele onderhoude is met die skoolhoofde gevoer, ten einde aan hulle die geleentheid te gee om onbevange hulle opinie oor skoolsukses in arm gemeenskappe, en hulle eie rol in die verwesenliking daarvan weer te gee. As 'n verifikasiemaatreël is adjunkhoofde, departementshoofde en lede van die skoolbeheerliggaam in fokusgroeponderhoude betrek. Vir albei tipes onderhoude het die onderhoudskedule die reeds genoemde taksonomie as vertrekpunt geneem, en die volgende sleutelvrae bevat:

- Wat beskou u as die belangrikste vereistes vir skoolbestuur in 'n arm gemeenskap?

- Hoe hou u die personeel en leerders gemotiveerd?

- Hoe verseker u dat alle betrokkenes optimaal en toegewyd deelneem aan die skool se bedrywighede?

- Hoe benader u evaluering en assessering in u skool?

- Wat beskou u as die belangrikste faktor vir skoolsukses in 'n arm gemeenskap? 
Elke skool is ten minste twee keer besoek, maar as gevolg van wedersydse tydsbeperkings was observasie van die fisiese fasiliteite en funksionering van die skole tot algemene indrukke beperk. Die skole se beleidsdokumente is bestudeer om 'n idee van die skooletos te kry, soos vergestalt in visiestelling, missiestelling en beleidsaspekte.

Geen pertinente struikelblokke in die reëlings vir en die eintlike uitvoering van die veldwerk is ondervind nie. Slegs in een geval moes 'n fokusgroeponderhoud herskeduleer word as gevolg van ' $n$ misverstand oor die tyd en plek daarvan.

\section{Bevindings}

Die bevindings van die veldwerk is georden as observasiebevindings, dokumentêre bevindings en onderhoudsbevindings.

\subsection{Observasiebevindings}

'n Parafrase van 'n deel van die veldnotas oor die milieu en toestand van een van die skole (geleë in Soshanguve, 'n groot stedelike woongebied naby Pretoria) som die aard van die omgewing en fasiliteite van die ander drie skole min of meer op:

Die woonhuise in die skoolomgewing is deurgaans klein baksteenstrukture, afgewissel deur tydelike sinkplaatstrukture. Sommige huise is netjies, maar die deursnee getuig van verwaarlosing met betrekking tot verfwerk, heinings en tuine. Die paaie is afwisselend teer- en grondpaaie - laasgenoemde is plek-plek vol slaggate. Die skoolgebou bestaan uit lang rye klaskamers en gee 'n afgeleefde indruk, met onaantreklike bruin verfwerk. Sementblaaie waarop vroeër tydelike klaskamers opgerig was, ontsier die skoolterrein plek-plek. By die ingang is ' $n$ klein blomtuin. Die ingang is netjies en die oprit en parkeerterrein is geplavei. Die skoolterrein is in die geheel netjies. Die klaskamers is binne ook netjies en funksioneel.

Die skoliere was almal in skooldrag geklee, en gedissiplineerde gedrag was opmerklik. Die leerder-opvoeder ratio in die vier skole het gewissel tussen 36:1 en 33:1.

\subsection{Dokumentêre bevindings}

Daar is aanvaar dat 'n ondersoek van skoolbeleidsdokumente lig kon werp op die etos en doelgerigtheid van die skole. Elkeen van die skole in die gevallestudies kon 'n stel skoolbeleidsdokumente voorsien wat kwessies soos toelatings, finansies, tienerswanger- 
skappe en skoolveiligheid gedek het. Twee skole het pertinente gedragsreëls vir leerders en onderwysers gehad. Elke skool het 'n spesifieke visie- en missiestelling gehad. Die essensie blyk uit die volgende voorbeeld van 'n visiestelling:

We aspire to be excellent performers in academic as well as extra-curricular activities;

en 'n missiestelling:

To develop learners' potential so that as adults they lead a life of self-fulfilment and active participation in a changing world.

Op grond van die dokumentêre analise is tot die gevolgtrekking gekom dat die skole in die gevallestudies hulself onomwonde verbind het tot die voorsiening van kwaliteitonderrig deur die vestiging van 'n konstruktiewe skooletos en die effektiewe realisering van doelwitte.

\subsection{Onderhoudsbevindings}

'n Oorkoepelende bevinding was dat daar groot ooreenstemming was tussen die data wat verkry is tydens die individuele onderhoude met die skoolhoofde en die data voortspruitend uit die fokusgroeponderhoude met die adjunkhoofde, departmentshoofde en lede van die skoolbeheerliggaam. Dieselfde hoë mate van ooreenstemming het geblyk ten opsigte van die landelik-stedelike veranderlikes. Data kon dus bloot saamgevoeg word vir analise en interpretasie.

In die volgende kort oorsig van die onderhoudsresponse word eers 'n samevatting gegee van die response op die eerste vier vrae (wat handel oor kwessies van bestuur, motivering, deelname en evaluering), waarna die response op die laaste vraag (wat handel oor die belangrikste faktor vir skoolsukses in arm gemeenskappe) onder die loep geneem word.

\subsubsection{Bestuur, motivering, deelname en evaluering}

Met betrekking tot die vereistes vir die bestuur van 'n suksesvolle skool in 'n arm gemeenskap, het deelnemers die essensiële rol van visionêre leierskap, uitgeoefen in 'n empatiese, bedagsame en aanpasbare leierskapstyl, beklemtoon. Die deelnemers het enige vorm van laissez faire afgewys - hulle het inteendeel die behoefte aan streng bestuursmaatreëls, veral met betrekking tot tydsbestuur (bv. deur ' $n$ jaarplan, rigiede roosters en stiptelikheid) en beheer- 
maatreëls (bv. by wyse van gedragsreëls vir opvoeders en leerders, die handhawing van dissipline in 'n klimaat van respek en verantwoordelikheid, en die sigbare teenwoordigheid van die bestuurskader - die sogenaamde bestuur-deur-rondstap) benadruk.

Deelnemers se response oor die tema motivering het veral vier sake beklemtoon, naamlik

- die behoefte aan 'n veilige omgewing;

- leerder- en personeelontwikkeling deur middel van onderlinge vertroue en hoë verwagtings;

- positiewe versterking deur middel van aansporingsmaatreëls en belonings; en

- oop en effektiewe kommunikasiekanale binne en buite die skool.

Wat die besprekingstema deelname betref, het die deelnemers die belangrikheid beklemtoon van gesamentlike, toegewyde eienaarskap van die skool se visie, gesamentlike besluitneming, en spanwerk in die vestiging van 'n kultuur van optimale beraadslaging tussen belanghebbendes.

Die bespreking van die tema evaluering het die onontbeerlike rol van effektiewe assesseringspraktyke (die belangrikheid van klasbesoeke, evaluering van leeruitkomste by wyse van leerderportefeuljes, betekenisvolle huiswerk en gereelde toetse), en selfevaluering deur die bestuurskader, onderwysers en leerders uitgelig.

Om saam te vat: Die besprekings oor die temas bestuur, motivering, deelname en evaluering het deelnemende leierskap en 'n kultuur van hoë verwagtings, gesamentlike eienaarskap deur al die belanghebbendes, optimale beraadslaging in besluitneming en deurlopende selfevaluering - alles binne 'n omgewing wat bevorderlik is vir leer - as belangrike faktore in die daarstelling van suksesvolle skole in arm gemeenskappe aangestip. Hierdie bevindings strook beduidend met dié van ander bestuursgevallestudies oor skoolsukses in arm gemeenskappe, in die VSA (Jacobson et al., 2005) en die Verenigde Koninkryk (Day, 2005).

\subsubsection{Belangrikste suksesfaktor?}

Die deelnemers is gevra om die enkele, belangrikste faktor vir skoolsukses in arm gemeenskappe uit te sonder. Dit was opvallend dat die deelnemers dit nie kon of wou doen nie. Hulle het aangevoer 
dat dit onmoontlik was om één enkele faktor uit te sonder as die allerbelangrikste. Die faktore wat genoem is, kan in twee temas saamgevat word, naamlik inspirasie en konsultasie.

- Inspirasie: Die skoolhoof se voorleef van 'n vasberade verbintenis tot die skoolvisie en waardes van regverdigheid en verantwoordelikheid, passie vir leer en onderrig, positiewe verwagtings en harde werk is aangedui.

- Konsultasie: Die skoolhoof beklemtoon beraadslaging en advies inwinning, spanwerk en oopdeurleierskap.

Die bevindings van die empiriese navorsing het aan die lig gebring dat die genoemde taksonomie (Mampuru, 2003:10-11) wel nuttig en bruikbaar is om aspekte van skoolsukses in arm gemeenskappe te oorweeg en te ondersoek. Dit het ook geblyk dat skoolsukses in arm gemeenskappe op verskeie faktore berus. Hierdie faktore is interafhanklik met mekaar, en moet beskou word as wedersydse aanvullende beginsels, houdings en aktiwiteite in die vestiging en voortdurende verbetering van 'n suksesvolle skool in 'n arm gemeenskap.

Literatuurgegewens bevestig die slotsom dat skoolbestuursukses in arm gebiede op 'n matriks van beginsels en praktyke berus. Jacobson et al. (2005:607) onderskei byvoorbeeld in hul empiriese data die beginsels van toerekenbaarheid, omgee en leer, en bring hierdie beginsels sinvol in verband met drie kernleierskapspraktyke in suksesvolle skoolbestuur, naamlik rigtinggewing, mensontwikkeling en institusionele herdefiniëring. Day (2005:575) konstateer op grond van sy gevallestudies dat 'n aantal kerntemas skoolbestuursukses in arm gemeenskappe kenmerk, waaronder die morele imperatief tot mensontwikkeling, hoë verwagtings, leergierigheid, onderlinge vertroue en passievolle toewyding. In 'n studie van suksesvolle privaatskole in arm gemeenskappe is bevind dat skoolsukses op ten minste tien kernfaktore berus, waaronder ' $n$ etos van omgee, klem op dissipline, hoogstaande dienslewering, noue samewerking van alle belanghebbendes en betrokkenheid by die wel en wee van die gemeenskap (Centre for Development and Enterprise (CDE), 2006:61).

\section{Bespreking}

Die toepassing van Mampuru (2003) se taksonomie het laat blyk dat die suksesfaktore in effektiewe skole wesenlik generies is, aangesien daar in die loop van die empiriese ondersoek geen blyke was 
van bykomstige of oortollige items nie. Tog het geblyk uit die bevindings van die empiriese navorsing, tesame met dié van talle gevallestudies van suksesvolle skole in arm gemeenskappe (AckerHocevar \& Touchton, 2002; Cole-Henderson, 2000; Day, 2005; Glidden, 1999; Haberman, 1999; Harris, 2002; Revilla \& De La Garza Sweeney, 1997; Jacobson et al., 2005; Jesse et al., 2004; Pollard-Durodola, 2003; Shanklin et al., 2003; Tivnan \& Hemphill, 2005; Walker \& Dimmock, 2005) dat sekere beklemtonings gegeld het. Ten opsigte van die skoolsuksesfaktore in arm gemeenskappe (dit wil sê in die oorkoming van al die agterstande wat deur armoede meegebring word) kan bepaalde beklemtonings onderskei word wat gekontrasteer kan word met waardes en praktyke wat dikwels vir skole (ook effektiewe skole) in die algemeen kan geld. Die kontras behels 'n klem op die volgende:

- visie en missie eerder as situasie;

- omgee eerder as onderrig;

- waardes eerder as doelwitte;

- uitnodiging eerder as reëling;

- geborgenheid eerder as funksionaliteit;

- respek eerder as verdraagsaamheid;

- verwagting eerder as aannames;

- saam eerder as afsonderlik;

- kwaliteit eerder as uitkoms;

- moeite doen eerder as plig doen;

- gemeenskapsfokus eerder as skoolfokus;

- bemagtiging eerder as ontwikkeling;

- inspanning eerder as vermoë (effort paradigm versus ability paradigm);

- sosiale geregtigheid eerder as maatskaplike apatie;

- vertroue eerder as kontrole;

- organisasie-leer eerder as organisasie-funksie;

- familie-besef eerder as groepbesef (dit wil sê samebinding eerder as samevoeging); 
- positiewe skoolklimaat eerder as professionele skoolklimaat;

- fokus op onderrig eerder as fokus op die skool;

- menslike behoeftes eerder as institusionele behoeftes; en

- transformasie-leierskap eerder as transaksie-leierskap.

Laasgenoemde kontras is eintlik wesenlik en bepaal grootliks die voorgenoemde kontraste. Stoll en Fink (1996:105-106) tref die volgende paslike onderskeid tussen transaksie- en transformasieleierskap: transaksieleierskap gaan oor die dienste-salaristransaksie tussen werkgewer en werknemer, en behels in wese doeltreffende skoolbestuur. Die fokus val op organisasiedoelstellings, aksieplanne, prosedures en doeltreffende taakverrigting. Transformasieleierskap daarenteen plaas allereers die klem op positiewe gesindheid, verhoudings en energieke deelname van elke persoon wat by die organisasie betrokke is - dit gaan om die transformasie van gevoelens en houdings, eerder as om take en prestasie. Hierdie leierskapstyl beklemtoon kultuur, eerder as bestuur in die verwesenliking van doelstellings. Variasies van transformasieleierskap is onder andere uitnodigende leierskap (Stoll \& Fink, 1996:108-117), verspreide leierskap (distributed leadership - Harris, 2002:17) en leergesentreerde leierskap (learning centred leadership - Day, 2005:578). Vanweë die mensgerigte en aanpasbare aard daarvan is transformasie- en aanverwante leierskapstyle verkieslik in onseker en onstabiele omstandighede (Stoll \& Fink, 1996:106).

Op grond van hierdie kontraste (as profiel van 'n suksesvolle skool in 'n arm gemeenskap) is gepoog om ter wille van teoriebou en praktykaanbevelings 'n oorkoepelende, allesomvattende tema te identifiseer - die spil waarom al die suksesfaktore draai. Dit het geblyk dat vennootskap as so 'n tema kan dien. Vennootskap veronderstel gemeenskaplike visie, beplanning, verwagtings, eienaarskap, deelname, betrokkenheid, spanwerk, toewyding en toerekenbaarheid, asook wedersydse respek en vertroue - almal kernelemente in die faktore wat in die onderhawige literatuur- en empiriese navorsing geïdentifiseer kon word as van belang vir skoolsukses in 'n arm gemeenskap. Die nosie vennootskap is ook inherent deel van Kritzinger (1996) se reeds genoemde "kontoere" in die benadering van die armoedevraagstuk.

Met vennootskap as sentrale tema is 'n model van sleutelfaktore vir skoolsukses in arm gemeenskappe ontwerp ten einde die relatiewe posisie van en die verhouding tussen hierdie faktore aan te dui. Daar is ook aangeneem dat so 'n model nuttig sal wees as 'n 
verwysingsraamwerk waarvolgens skole in arm gemeenskappe hulle dienslewering kan assesseer. Dit kan ook nuttig wees vir die voor-diens- en in-diensbestuursopleiding van skoolhoofde en lede van die beheerliggame van sodanige skole. Die model word in Figuur 1 uitgebeeld.

\section{Figuur 1: Model van sleutelfaktore vir skoolsukses in arm gemeenskappe}

\begin{tabular}{|lll|}
\hline Waardes & $\longrightarrow$ & Meganismes \\
-Visie & Vennootskap & -Bestuur \\
-Missie & & - - Motivering \\
-Etos & & -Deelname \\
& & -Evaluering \\
& & \\
Kultuur: Toewyding $\leftrightarrow$ Leierskap: Deelnemend $\leftrightarrow$ Oriëntasie: Verwagtings \\
\hline
\end{tabular}

Op grond van die navorsingsbevindings beeld die model die volgende uit: die nosie vennootskap onderlê alle waardes (soos vergestalt in die visie, missie en etos) en meganismes (bestuur, motivering, deelname en evaluering - vgl. taksonomie) van die skool. Dit kom tot uiting in 'n skoolkultuur van algemene toewyding aan skoolsukses, deelnemende leierskapstyl, en 'n doelgerigte oriëntasie met betrekking tot die verwesenliking van die verwagtings van alle belanghebbers by die skool. Die skoolkultuur, -leierskap en -oriëntasie is vanselfsprekend 'n geïntegreerde geheel. Die model kan in baie fyner besonderhede gepresiseer word deur die byvoeging van subkategorieë en onderafdelings, om as moontlike raamwerk vir 'n selfevalueringsinstrument te dien.

Dit is vervolgens nodig geag om die vennootskapsmodel teoreties te verifieer en wel op tweërlei wyse.

- Verifikasie op grond van die kompleksiteitsteorie. 'n Arm gemeenskap is wesenlik 'n maatskaplik onstabiele gemeenskap vanweë die voorkoms van geweld, misdaad en drank- en dwelmmisbruik. As sodanig kan dit dikwels 'n onvoorsiene, beduidende en meestal problematiese invloed op die skool uitoefen. Gevolglik is geoordeel dat die kompleksiteitsteorie 'n 
geskikte raamwerk is vir die evaluering van die vennootskapsmodel se teoretiese geldigheid in die armoedekonteks.

- Verifikasie op grond van die lerende-organisasieteorie (hierna LO-teorie). Hierdie teorie beklemtoon die kernrol van voortdurende leer (veral saam leer, leer-in-vennootskap) in organisasies. Daar is geoordeel dat die LO-teorie veral toepaslik kan wees vir skole in arm gemeenskappe vanweë die aansluiting by die "saam-strategie" vir werk in arm gemeenskappe (vgl. Kritzinger (1996) se genoemde "kontoere").

\subsection{Kompleksiteitsteorie vis-d̀-vis die vennootskapmodel}

Mansfield (2003) gee 'n sinvolle sinopsis van die belangrikste eienskappe van die kompleksiteitsteorie en die rol daarvan in onderwysleierskap (vgl. ook Morrison, 2003 en O'Day, 2002). Volgens Mansfield is die kompleksiteitsteorie gebaseer op die empiriese feit dat ontwikkelings in die natuurlike wêreld dikwels nieliniêr, onstabiel en onstuimig is. Toegepas op die wêreld van menslike organisasie word besef dat onvoorspelbaarheid en disekwilibrium eintlik voordelig is, want dit inspireer tot spontane aanpasbaarheid en nuwe kreatiewe ontwikkelings. Diversiteit, paradoks en meningsverskille kan dus beskou word as noodsaaklike elemente van innovasie. Doeltreffende organisasies funksioneer gevolglik deur die skep en funksionering van netwerke en spanne wat buigbaar is in hulle pogings om die beste oplossings te vind. Vir enige beplanning, ontwikkeling en leer is deelname en kommunikasie onontbeerlik.

So complexity thinking leaders must be flexible, people-centred visionaries who do not hold on to power, but disperse it, who listen and are led by their people. Above all they must be prepared to find new routes to agreed destinations, and not be afraid of getting lost, trusting that the edge of chaos is the grounds of real creativity and development for all (Mansfield, 2003:3).

Doll (1989:3) som die ideale uitwerking van die kompleksiteitsteorie in onderwysinrigtings op met die frase: "More dancing, less marching".

In terme van die vennootskapsmodel (vgl. Figuur 1) blyk dit dat die identifisering van vennootskap as 'n sleutelfaktor in skoolsukses wel volgens die kompleksiteitsteorie houdbaar is. Die sleutelelemente van organisatoriese kompleksiteitsteorie (bv. selforganisering, diversiteit, netwerke, groepdeling en kommunikasie), soos kortliks 
aangetoon, kan direk verbind word met die nosie vennootskap. Met hierdie model as vertrekpunt kan die belangrikste aspekte van die toepassing van die kompleksiteitsteorie in die skoolpraktyk soos volg uitgebeeld word:

Vennootskap: netwerke

Waardes: buigbaarheid; kreatiwiteit

Meganismes: selforganisering; kommunikasie

Leierskap: $\quad$ visionêr; mensgesentreerd

Verwagtings: probleemoplossingsvaardighede; innovasie

Toewyding: betrokkenheid

\subsection{Lerende-organisasieteorie vis-ò-vis die vennoot- skapsmodel}

In haar boek, The school as a learning organisation, voorsien Moloi (2002:2-12) 'n betekenisvolle sinopsis van die LO-teorie. Sy haal Senge (1990) aan in haar beskrywing van 'n lerende organisasie as 'n plek waar nuwe denkpatrone aangekweek word, waar kollektiewe aspirasies gekoester word en waar mense voortdurend leer om gesamentlik op te tree. Lerende organisasies word wesenlik onderskei van tradisionele, meer outoritêre organisasies deur hul bemeestering van vyf leerdissiplines (cf. Senge, 1990). Hierdie leerdissiplines is naamlik individuele leer (leer om persoonlike denkvermoë te benut en uit te brei), geestesaktiwiteit (diepsinnige refleksie oor persoonlike opvattings), gesamentlike visie (gedeelde voorstellings van toekomsideale), spanleer (gespreks- en groepsdenke-vaardighede om kollektiewe intelligensie te ontwikkel), en sisteemdenke (fokus op die "groot prentjie"-perspektief en die besef hoe individuele aksies al die ander mense raak). Laasgenoemde dissipline omvat die ander op grond van die aksioma dat die funksionering van sisteme deur onderlinge verbande bepaal word. Lerende organisasies het gemeenskaplike kenmerke: hulle assesseer hulle vaardighede en leerkapasiteit voortdurend; hulle beloon werkprestasie en hulle het buigbare strukture om werknemers tot vrye en oop denke te inspireer. Deelname aan die werksaamhede van interdepartementele taakspanne gee werknemers die geleenthede om van kollegas te leer. Dit moedig ook 'n kultuur van openhartigheid en voortdurende terugvoer aan. 'n Lerende organisasie is in staat om verandering proaktief te hanteer en betekenisvolle transformasie vind voortdurend plaas as gevolg 
van optimale geleenthede vir deurlopende leer. Leer vind plaas op individuele, span-, organisatoriese en sosiale vlakke, en "a deep sense of commitment provides the energy to succeed" (Moloi, 2002:5).

Hierdie kort samevatting laat onmiskenbaar blyk dat die nosie vennootskap prominent figureer in die wesenlike aspekte van LOteorie. Dit is inderdaad van sleutelbelang in die strewe na en die voortdurende verbetering van 'n skool as 'n lerende organisasie. Volgens die vennootskapsmodel (vgl Figuur 1) kan die toepassing van die LO-teorie in die skoolpraktyk soos volg uitgebeeld word:

Vennootskap: sisteem

Waardes: $\quad$ kreatiewe denke; sisteemdenke

Meganismes: spanwerk; selfassessering; belonings; buigbare strukture; kontekse vir voortdurende leer

Leierskap: gesamentlike visie; veranderingsbestuur

Verwagtings: deelname; voortdurende leer; uitbreiding van persoonlike kapasiteit; spanleer

Toewyding: belangrikste dryfveer; "energiebron"

Dit het geblyk dat die vennootskapsmodel vir skoolsukses in arm gemeenskappe (vgl. Figuur 1) wel die toets van teoretiese geldigheid kan deurstaan. Dit is egter waar dat verdere uitbreiding en verfyning van dié model raadsaam is in die toepassing daarvan vir bepaalde doeleindes (bv. as assesseringsinstrument). Verdere teoretiese stawing van dié model kan ook gedoen word op grond van, byvoorbeeld, uitnodigende-onderwysteorie.

\section{Gevolgtrekkings}

Die model in sy basiese vorm kan alreeds bruikbaar wees om skoolbesture in arm gemeenskappe te lei in hulle besinning oor die belangrikheid en praktyk van vennootskap in die realisering van skoolwaardes en skoolmeganismes, en hoe dit die aard van toewyding, leierskap en verwagtings in die skool raak. Onderwysdepartemente en hulle substrukture behoort dié model ook te beproef deur dit te verfyn vir gebruik in bepaalde arm gemeenskappe vir die verbetering van onderwysvoorsiening aldaar.

Die model kan ook gebruik word as 'n raamwerk vir die ontwikkeling van 'n selfassesseringsinstrument vir skole in arm gemeenskappe. 
Hierdie instrument behoort meer te doen as die blote identifisering van sterk en swak punte - dit behoort ook die aksies aan te dui wat uitgevoer moet word om geïdentifiseerde swakhede teë te werk.

Laastens kan aanvaar word dat die vennootskapsmodel (vgl. Figuur 1), met bepaalde klemverskuiwings, wat verder nagevors behoort te word, ook segswaarde mag hê vir skole in meer gegoede buurte.

\section{Geraadpleegde bronne}

ACKER-HOCEVAR, M. \& TOUCHTON, D. 2002a. How principals level the playing field of accountability in Florida's high-poverty/low-performing schools. Part 1: The intersection of high-stakes testing and effects of poverty on teaching and learning. International Journal of Educational Reform, 11(2):106-124.

ACKER-HOCEVAR, M. \& TOUCHTON, D. 2002b. How principals level the playing field of accountability in Florida's high-poverty/low-performing schools. Part 3: Effects of high-poverty schools on teacher recruitment and retention. International Journal of Educational Reform, 11(4):334-346.

ANON. 2002. The best and worst of schools. Sunday Times: 22, 24 Feb.

BOWRING-CARR, C. 1997. Effective learning in schools: how to integrate learning and leadership for a successful school. London: Pitman.

CENTRE FOR DEVELOPMENT AND ENTERPRISE (CDE). 2006. Accelerating shared growth: making markets work for the poor in South Africa. Report commissioned by ComMark Trust. http://www.cde.org.za Date of access: 13 Apr. 2006.

CHAMBERS, R. 1994. Rural development: putting the last first. Harlow: Longman.

CLINARD, M.B. 1970. The role of motivation and self-image in social change in slum areas. (In Allen, V.L., ed. Psychological factors in poverty. Chicago: Markham.

COLE-HENDERSON, B. 2000. Organizational characteristics of schools that successfully serve low-income urban African American students. Journal of Education for Students Placed at Risk, 5(1 \& 2):77-91.

DAVIES, B. 1997. Reengineering and total quality in schools: how to reform and restructure your school to meet the challenge of the future. London: Pitman.

DAY, C. 2005. Sustaining success in challenging contexts: leadership in English schools. Journal of Educational Administration, 43(6):573-583.

DOLL, W.E. 1989. Complexity theory in the classroom. Educational Leadership: $65-70$, Sept.

ENGLISH, F.W. \& HILL, J.C. 1994. Total quality education: transforming schools into learning places. Thousand Oaks: Corwin.

FARRELL, E.W. 1994. Self and school success: voices and core of inner-city students. Albany: State University of New York Press.

GEWIRTZ, G. 1998. Can all schools be successful? An exploration of school success. Oxford Review of Education, 24(4):439-457. 
GLIDDEN, H.G. 1999. Breakthrough schools: characteristics of low-income schools that perform as though they were high-income schools. ERS Spectrum: 21-26, Spring.

GONDER, P.O. 1983. Anatomy of school success. Executive Educator, 5(1):2627.

HABERMAN, M. 1999. Victory at Buffalo Creek: what makes a school serving low income Hispanic children successful? Instructional Leader, 12(2):1-5.

HARRIS, A. 2002. Effective leadership in schools facing challenging contexts. School Leadership \& Management, 22(1):15-26.

HORNE, H. \& BROWN, S. 1997. 500 tips for school improvement. London: Kogan Page.

JACOBSON, S.L, JOHNSON, L, YLIMAKI, R. \& GILES, C. 2005. Successful leadership in challenging US schools: enabling principles, enabling schools. Journal of Educational Administration, 43(6):607-618.

JESSE, D, DAVIS, A. \& POKORNY, N. 2004. High-achieving middle schools for Latino students in poverty. Journal of Education for Students Placed at Risk, 9(1):23-45.

KAMPER, G.D. 2001. Poverty: perspectives and educational implications. South African Journal of Education, 21(1):109-113.

KRITZINGER, J.J. 1996. Die stryd teen armoede. Potchefstroom: Instituut vir Reformatoriese Studie. (Studiestuk, 340.)

LEWIS, J. 1993. Implementing total quality in education to produce great schools. New York: National Center to Save our Schools.

MAMPURU, M.E. 2003. Determinants of school success in disadvantaged environments. Pretoria: University of South Africa. (M.Ed. dissertation unpublished.)

MANSFIELD, D. 2003. Complexity theory and educational leadership. http://www.ncsl.org.uk/media Date of access: 18 May 2005.

MARISHANE, R.N. 1999. Partnerships in school governance: foundation for reform and restructuring. Pretoria: University of South Africa. (M.Ed. dissertation - unpublished.)

MAY, J. \& GOVENDER, J. 1998. Poverty and inequality in South Africa. http://www.sacs.org.za/pubserv/1998 Date of access: 23 Oct. 1998.

MOLOI, K.C. 2002. The school as a learning organisation. Pretoria: Van Schaik. MORRISON, K. 2003. Complexity theory and curriculum reforms in Hong Kong. Pedagogy, Culture \& Society, 11(2):279-302.

NAPTOSA see NATIONAL PROFESSIONAL TEACHERS ORGANISATION OF SA

NATIONAL COMMISSION ON EDUCATION. 1996. Success against the odds: effective schools in disadvantaged areas. London: Routledge.

NATIONAL PROFESSIONAL TEACHERS ORGANISATION OF SA. 2003. Access to free and quality education. http://www.naptosa.org.za Date of access: 26 Jun. 2006

NCE

see NATIONAL COMMISSION ON EDUCATION

O'DAY, J. 2002. Complexity, accountability and school improvement. Harvard Educational Review, 72(3):293-329.

PARSONS, C. 1994. Quality improvement in education: case studies in schools, colleges and universities. London: David Fulton.

PIETERSE, H.C. 2001. Prediking in 'n konteks van armoede. Pretoria: Uitgewers. 
POLLARD-DURODOLA, S. 2003. Wesley Elementary: a beacon of hope for atrisk students. Education and Urban Society, 36(1):94-117.

PURKEY, W.W. 2000. What students say to themselves: internal dialogue and school success. Thousand Oaks: Corwin.

RDP see RECONSTRUCTION AND DEVELOPMENT PROGRAMME

RECONSTRUCTION AND DEVELOPMENT PROGRAMME. 1995. Poverty in South Africa. Pretoria: World Bank.

REID, K., HOPKINS, D. \& HOLLY, P. 1987. Towards the effective school: the problems and some solutions. Oxford: Blackwell.

RESEARCH SURVEYS. 2005. Poverty, poverty and more poverty. Di-nam'ik: 1, Dec.

REVILLA, A.T. \& DE LA GARZA SWEENEY, Y. 1997. Low income does not cause low school achievement: creating a sense of family and respect in the school environment. IDRA Newsletter, 24(6):4, 8.

SALLIS, E. 1992. Total quality management in education. Philadelphia: Kogan Page.

SCHEETS, M. \& BENSON, T. 1994. Structuring schools for success: a view from the inside. Thousand Oaks: Corwin.

SENGE, P.M. 1990. The fifth discipline: the art and practice of the learning organization. New York: Doubleday.

SHANKLIN, N., KOZLESKI, E.B., MEAGHER, C., SANDS, D., JOSEPH, O. \& WYMAN, W. 2003. Examining renewal in an urban high school through the lens of systemic change. School Leadership \& Management, 23(3):357-378.

STOLL, S. \& FINK, D. 1996. Changing our schools. Buckingham: Open University Press.

TERRE BLANCE, M., DURRHEIM, K. \& PAINTER, D., eds. 2006. Research in practice. Cape Town: University of Cape Town Press.

TERREBLANCE, S. 2004. Armoede in Suid-Afrika. Tydskrif vir Geesteswetenskappe, 44(2 \& 3):213-240.

TIVNAN, T. \& HEMPHILL, L. 2005. Comparing four literacy reform models: patterns of first-grade achievement. The Elementary School Journal, 105(5):419-441.

TOWNSEND, T. 1997. Restructuring and quality: issues for tomorrow's schools. London: Routledge.

VISSCHER, A.J. 1999. Managing schools towards high performance: linking school management theory to the school effectiveness knowledge base. Lisse: Exton Swets \& Zeitlingen.

WALKER, A. \& DIMMOCK, C. 2005. Leading the multi-ethnic school: research evidence on successful practice. Educational Forum, 69:291-304, Spring.

WEST-BURNHAM, J. 1997. Managing quality in schools: effective strategies for quality based school improvement. London: Pitman.

\title{
Kernbegrippe:
}

\author{
armoede \\ skoolbestuur \\ skooleffektiwiteit \\ skoolleierskap \\ skoolsukses
}




\section{Key concepts:}

poverty

school effectiveness

school leadership

school management

school success 